\title{
Synthesis, Characterization and Antibacterial Activity of 2-Phenylsulphonamide Derivatives of Some Amino Acids
}

\author{
Ikpa Chinyere B.C. ${ }^{1{ }^{*}}$, Okoro Uchechukwu C. ${ }^{2 b}$, Ubochi Collins I. ${ }^{1 \mathrm{c}}$ \\ and Nwanorh Kieran O. ${ }^{1 \mathrm{~d}}$ \\ ${ }^{1 *}$ Department of Chemistry, Imo state University Owerri, Nigeria, \\ ${ }^{2}$ Department of Chemistry, University of Nigeria, Nsukka, Nigeria. \\ a*ikpacbc@gmail.com, buchechukwu.okoro@unn.edu.ng, 'ubochicollins@yahoo.com, \\ oharleykieran@yahoo.com
}

\section{Keywords; 2-Phenylsulphonamide; Amino acids; Antibiotics; Benzenesulphonylchloride;} Synthesis.

\begin{abstract}
The 2-phenylsulphonamide derivatives of amino acids were synthesis by simple substitution of benzenesulphonylchloride (6) with amino acids (1-5) containing pharmacological active functionalities. Structures of the synthesised compounds $(7 \mathrm{a}-7 \mathrm{e})$ were characterised using FT-IR, NMR $\left({ }^{1} \mathrm{H},{ }^{13} \mathrm{C}\right)$ and elemental analysis. The anti bacterial activities of the synthesised compounds were evaluated against gram positive bacteria: Staph and Streptococcus, gram negative bacteria: E-coli, Klebsiella, Proteus, and pseudomonas using $200 \mu 1 \mathrm{of} 10 \mathrm{mg} / \mathrm{ml}$ and minimum inhibitory concentration (MIC) were also determined. The compounds exhibited effective anti bacterial properties though some are not more active than the standard drug ciprofloxacin.
\end{abstract}

\section{Introduction}

The importance of sulphonamides were first realised when sulphonylamide a key analogue of sulphonamide was reported to be the first antibacterial drug [1]. Sulphonamides represent a large and important class of medicinally important compounds which are extensively used as drugs that have been in continuous use in treating both antibacterial and non antibacterial diseases [2]. Clinically,_Sulphonamide drugs have been in use because of their various biological properties such as anti-tumour [3], anti-thyroid [4], hypoglycaemic agent [5], carbonic anhydrase inhibitor [6], antiinflammatory [7], diuretic agent [8], anti-impotent drugs [9], anti-convulscant [10], anti-cancer [11], anti-retroviral [12], anti-hypertensive [13], and anti-malaria drugs [14]. Today, Sulphonamides could be classed as the lead in the fight against fungi infections in the chemotherapeutic world following the discovery of $\mathrm{N}$ - pyridine-2-yl-4-methylphenylsulphonamides [15]. Sulphonamide derivatives such as Schiff bases have been used for several biological applications, for instance as antifungal agents used to inhibit the germination of Colletotrichum gloeosporioides spores on mango [16]. Other sulphonamide derivatives like fluorinated and nitroginated sulphonamides exhibited potent antimicrobial agents [17]. The rapid development of widespread resistance of sulphonamide drugs [18] has called for the research of new potent and toxic free sulphonamide drugs.

In this work we report the synthesis of the 2-phenylsulphonamide derivatives of amino acids of pharmacologically active functionalities and their antibacterial activities. Para-toluene sulphonamide derivatives which were analogues of the synthesised 2-phenylsulphoamide derivatives of amino acids were also recorded as broad spectrum antibiotics because of their antibacterial activities [19].

\section{Materials and methods}

\section{General Chemistry}

All chemicals were purchased from Sigma Aldrich. IR spectra were recorded with FT-IR $(\mathrm{KBr})$ in $\mathrm{cm}^{-1}$. Melting points were determined with melting point apparatus and are uncorrected. 
NMR spectra were recorded at operating frequency of $\mathrm{F}_{1}$ and $\mathrm{F}_{2} ; 300.1300000 \mathrm{MHz}$ for ${ }^{1} \mathrm{H}$ and $\mathrm{F}_{1} 75.4752953 \mathrm{MHz}, \mathrm{F}_{2} 75.4677490 \mathrm{MHz}$ for ${ }^{13} \mathrm{C}$. Results were presented as chemical shifts $\delta$ in ppm, J. Values in Hz, multiplicity are shown as abbreviations; s (singlet), d (doublet), t (triplet), $\mathrm{q}$ (quartet) and $\mathrm{m}$ (multiplet).

General procedure for synthesis of 2-phenylsulphonamide derivatives of amino acids (7a-7e) [20].

$\mathrm{Na}_{2} \mathrm{CO}_{3}(5.565 \mathrm{~g}, 52.5 \mathrm{mmol})$ was added to a solution of amino acids (1-5) $(25 \mathrm{mmol})$ in $\mathrm{H}_{2} \mathrm{O}$ [30mL] at $0^{\circ} \mathrm{C}$, cooled to $-5^{\circ} \mathrm{C}$ followed by addition of benezenesulphonyl chloride (6) $[3.84 \mathrm{ml}$, $30 \mathrm{mmol}$ in three portions over a period of $1 \mathrm{~h}$. The reacting mixture was warmed to room temperature and allowed to stir for $4 \mathrm{~h}$. Upon completion of the reaction, which was monitored with TLC using mixture of $\mathrm{CHCl}_{3} / \mathrm{CH}_{3} \mathrm{OH}$ [9:1], 20\% concentrated aqueous $\mathrm{HCl}$ solution was added with continuous stirring to avoid foaming on the surface until the $\mathrm{pH}$ of 2 was attained. The solid that was separate out was allowed to settle down over night and isolated via suction filtration. The filtered crude product was washed with tartaric acid of $\mathrm{pH} 2.2$ buffer and dried in a vacuum oven at $60^{\circ} \mathrm{C}$ for $12 \mathrm{~h}$ to afford 2-phenylsulphonamide derivatives (7a-7e) in good to excellent yield [54.13\% $-69.28 \%]$.

\section{2-[Phenylsulphonamido]propanoic acid (7a).}

The amino acid is alanine (1) $[1.11 \mathrm{~g} 25 \mathrm{mmol}]$. Theoretical yield is $5.73 \mathrm{~g}$, experimental $3.97 \mathrm{~g}$ (69.28\%), The molecular formula is $\mathrm{C}_{5} \mathrm{H}_{11} \mathrm{NO}_{4} \mathrm{~S}$, Weight is $229.25 \mathrm{~g}, \mathrm{R}_{\mathrm{f}} 0.89$ and MP. $118-119^{0} \mathrm{C}$. FT-IR (KBr) $\left(\mathbf{c m}^{-1}\right) ; 1160.11(\mathrm{~S}=0)$, 3424.73(-NH- stretch), 1700.31(C=O, acid), 3315.74(-OHcarboxylic). ${ }^{1} \mathbf{H}$ NMR $(\delta \mathrm{H}) ; 0.79\left(3 \mathrm{H}_{\mathrm{d}} . \mathrm{J} .592 . \mathrm{CH}_{3}\right), 1.94\left(1 \mathrm{H}_{\mathrm{q}}\right), 3.1 .05(\mathrm{CH}), 3.49-3.5\left(1 \mathrm{H}_{\mathrm{d}} . \mathrm{J} .1 .99\right)$, $4.33(-\mathrm{NH}), 7.52\left(1 \mathrm{H}_{\mathrm{t}}, \mathrm{J} .3 .13, \mathrm{Ar}-\mathrm{H}\right), 7.76\left(1 \mathrm{H}_{\mathrm{t}}, \mathrm{J} .2 .04, \mathrm{Ar}-\mathrm{H}\right), 8.01-7.94(\mathrm{OH}-\mathrm{J} .1 .00),{ }^{13}$ C NMR $(\delta \mathrm{C})$; 141.59 (C-1), 132.73(C-2), 126.93(C-3), 129.52 (C-4), 61.71 (C-5), 173.55 (C-1'), 30.83(C-2'), $19.43\left(\mathrm{C}-3^{\prime}\right)$.

\section{2-[Phenylsulphonamido]acetic acid (7b).}

The amino acid is glycine (2) [0.94g $25 \mathrm{mmol}]$. Theoritical yeild is $5.38 \mathrm{~g}$, experimental $3.52 \mathrm{~g}$ $(65.43 \%)$. The molecular formula is $\mathrm{C}_{8} \mathrm{H}_{9} \mathrm{NO}_{4} \mathrm{~S}$; Weight is $215.25 \mathrm{~g}, \mathrm{R}_{\mathrm{f}} 0.61$ and MP. $102-103^{\circ} \mathrm{C}$. FT-IR $(\mathrm{KBr})\left(\mathrm{cm}^{-1}\right) ; 1140.92(\mathrm{~S}=0), 3417.01 \quad(-\mathrm{NH}-\mathrm{stretch}), 1719.6 \quad(\mathrm{C}=\mathrm{O}$ acid$), 3321.52$ (OH- carboxylic). ${ }^{1} \mathrm{H}$ NMR $(\delta \mathrm{H}) ; 3.5\left(2 \mathrm{H}_{\mathrm{t}} \mathrm{J} .2 .02, \mathrm{CH}-\mathrm{NH}\right), 7.63\left(1 \mathrm{H}_{\mathrm{t}} \mathrm{J} .2 .01 \mathrm{Ar}-\mathrm{H}\right), 7.75\left(1 \mathrm{H}_{\mathrm{d}}\right.$, J.3.01,Ar-H), 7.83(1 $\mathrm{H}_{\mathrm{t}}$ J.2.01 Ar-H), $8.06(\mathrm{NH}, \mathrm{J} .1 .00), 12.63(\mathrm{OH}, \mathrm{J} .0 .54) .{ }^{13} \mathrm{C}$ NMR $(\delta \mathrm{C})$; 141.14(C-1),132.85 (C-2 \& C-6), 126.91 (C-3 \&C-5), 129.52 (C-4), 170.70 (C-1'), 44.27 (C-2').

\section{2-[Phenylsulphonamido]-4-methylpentanoic acid (7c)}

The amino acid is leucine (3) [1.64g $25 \mathrm{mmol}$. Theoretical yield is $6.03 \mathrm{~g}$, experimental $4.21 \mathrm{~g}$ $(68.82 \%)$. The molecular formula is $\mathrm{C}_{10} \mathrm{H}_{11} \mathrm{NO}_{4} \mathrm{~S}$; Weight is $241.25 \mathrm{~g}, \mathrm{R}_{\mathrm{f}} 0.83$ and MP. $100-101^{0} \mathrm{C}$. FT-IR $(\mathrm{KBr})\left(\mathrm{cm}^{-1}\right) ; 1162.65(\mathrm{~S}=\mathrm{O}), 3585.79(\mathrm{NH}), 3248.23 \quad(\mathrm{OH}$-carboxylic $), 1710.92(\mathrm{C}=\mathrm{O})$. ${ }^{1} \mathrm{HNMR}(\delta \mathrm{H}) ; 0.80\left(3 \mathrm{H}_{\mathrm{d}}, \mathrm{J} .2 .94\right.$ of $\left.\mathrm{CH}_{3}\right), 0.87\left(3 \mathrm{H}_{\mathrm{d}}, \mathrm{J} .3 .68 \mathrm{CH}_{3}\right), 1.59\left(1 \mathrm{H}_{\mathrm{m}}, \mathrm{J} .3 .34, \mathrm{CH}\right), 3.71\left(1 \mathrm{H}_{\mathrm{t}}\right.$, J.1.32, $\left.\mathrm{CH}_{2}\right), 4.35(-\mathrm{NH}-), 7.36\left(1 \mathrm{H}_{\mathrm{t}}, \mathrm{J} .0 .53, \mathrm{Ar}-\mathrm{H}\right), 7.63\left(1 \mathrm{H}_{\mathrm{t}} \mathrm{J} .3 .72, \mathrm{Ar}-\mathrm{H}\right), 7.86\left(1 \mathrm{H}_{\mathrm{d} . J} \mathrm{~J} .2 .50 \mathrm{Ar}-\mathrm{H}\right)$, 8.13(-OH. J.1.00), ${ }^{13} \mathrm{C}$ NMR ( $\left.\delta \mathrm{C}\right) ; 144.57(\mathrm{C}-1), 132.25$ (C-2), 126.06 (C-3), 129.38 (C-4), 126.89 (C-5), 122.75 (C-6), $173.69\left(\mathrm{C}-1^{\prime}\right), 54.44$ (C-2'), 24.30 (C-3'), 41.36(C-4'), 23.00 (C-5'), $21.43\left(\mathrm{C}-6^{\prime}\right)$.

\section{2-[Phenylsulphonamido]-3-phenylpropanoic acid (7d).}

The amino acid is phenylalanine (4) $[2.06 \mathrm{~g} 25 \mathrm{mmol}]$. Theoretical yield is $7.63 \mathrm{~g}$, experimental $4.13 \mathrm{~g}(54.13 \%)$. The molecular formula is $\mathrm{C}_{15} \mathrm{H}_{15} \mathrm{NO}_{4} \mathrm{~S}$; Weight is $305.35 \mathrm{~g}, \mathrm{R}_{\mathrm{f}} 0.72$ and MP. $108-109^{\circ} \mathrm{C}$. FT-IR $(\mathrm{KBr})\left(\mathrm{cm}^{-1}\right) ; 1162.15(\mathrm{~S}=0), 3352.39(-\mathrm{OH}-), 3423.76\left(-\mathrm{NH}-2^{\circ}\right.$ Amine), $1686.81(\mathrm{C}=\mathrm{O}$ stretch$), 1445.7(\mathrm{C}=\mathrm{C}$ weak $) .{ }^{1} \mathrm{H}$ NMR $(\delta \mathrm{H}) ; \quad\left[2.70-3.00(\mathrm{Ph}-\mathrm{H}), 3.87-3.90\left(2 \mathrm{H}_{\mathrm{d}}\right.\right.$, $\left.\mathrm{CH}_{2}-\mathrm{Ph}\right), 3.92-3.95\left(1 \mathrm{H}_{\mathrm{t}}, \mathrm{CH}-\mathrm{NH}\right), 4.36(\mathrm{NH})$, J. 34.63], [7.12-7.24(1 $\left.\mathrm{H}_{\mathrm{t}} \mathrm{Ar}-\mathrm{H}\right), 7.41-7.44\left(1 \mathrm{H}_{\mathrm{t}}\right.$ $\mathrm{Ar}-\mathrm{H}), \quad 7.64-7.61\left(1 \mathrm{H}_{\mathrm{d}}\right)$, J.5.27], 8.27-8.30(1H. Ar-H), 12.62(-OH, J.2.70). ${ }^{13} \mathrm{C}$ NMR $(\delta \mathrm{C})$; 145.41(C-1), 143.00 (C-2), 126.92 (C-3), 138.88 (C-4), 125.98(C-5), 129.91 (C-6), 21.38 (C-7), $173.70-173.56\left(\mathrm{C}-1^{\prime}\right), 51.56\left(\mathrm{C}-2^{\prime}\right), 18.86\left(\mathrm{C}-3^{\prime}\right)$. 


\section{2-[Phenylsulphonamido]-3-methylbutanoic acid (7e).}

The amino acid is valine (5) [1.46g $25 \mathrm{mmol}$. Theoretical yield is $6.43 \mathrm{~g}$, experimental $3.52 \mathrm{~g}$ (56.30\%). The molecular formula is $\mathrm{C}_{11} \mathrm{H}_{15} \mathrm{NO}_{4} \mathrm{~S}$; Weight is $257.31 \mathrm{~g}, \mathrm{R}_{\mathrm{f}} 0.68$ and MP. $141-142^{0} \mathrm{C}$. FT-IR $(\mathrm{KBr})\left(\mathrm{cm}^{-1}\right) ; 1167.94(\mathrm{~S}=\mathrm{O}), 3413.15\left(\mathrm{NH}\right.$ of $2^{\circ}$ Amine $), 1707.06(\mathrm{C}=\mathrm{O}$ stretch $), 2969.51$ (C-C sat), 1550.82 (Ar), 3310.92 (-OH-). ${ }^{1} \mathrm{H}$ NMR $(\delta \mathrm{H}) ; 0.81-0.76\left(3 \mathrm{H}_{\mathrm{d}} . \mathrm{J} .0 .17 . \mathrm{CH}_{3}\right)$, 1.98-1.87(3H $\mathrm{H}_{\mathrm{d}}, \quad$ J.0.94. $\left.\mathrm{CH}_{3}\right), \quad 3.4-3.49\left(1 \mathrm{H}_{\mathrm{d}}-\mathrm{CH}\right), 4.34$ (NH.J. 0.18), 4.96-5.35(OH moity),

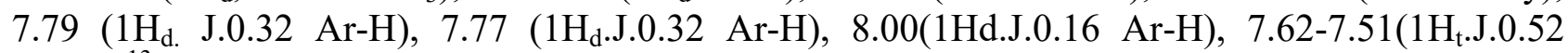
Ar-H), ${ }^{13} \mathrm{C}$ NMR (סC); 172.63(C-1), 141.52 (C-2), 129.33 (C-3), 126.93 (C-4), 72.59 (C-5), 132.73 (C-6), $172.57\left(\mathrm{C}-1^{\prime}\right), 61.70\left(\mathrm{C}-2^{\prime}\right), 30.82\left(\mathrm{C}-3^{\prime}\right), 19.41\left(\mathrm{C}-4^{\prime}\right), 19.23\left(\mathrm{C}-5^{\prime}\right)$.

\section{Evaluation of antibacterial activity of synthesised compounds}

\section{Preparation Inoculums}

The standard clinical isolated organisms of Staphylococcus aurous, Pseudomonas, Streptococcus, klebsiella, Escherichia coli and Proteus were obtained from FMC Owerri and the analysis was carried at Department of Medical Science Laboratory Imo state University. The strains of the organisms were propagated on nutrient agar plates and maintained at $4^{0} \mathrm{c}$. The isolates were sub-cultured in nutrient broth at $37^{\circ} \mathrm{C}$ for $8 \mathrm{~h}$ prior to antibacterial testing.

\section{Antibacterial sensitivity testing of compounds}

Agar well diffusion technique as described by Adeniyi et al [21] was used to determine the antibacterial activity of the synthesised compounds. Sensitivity test agar plates were inoculated with $0.1 \mathrm{ml}$ of an overnight culture of each bacteria strain (equivalent to $10^{8} \mathrm{CFU} / \mathrm{ml}^{-1}$ ). The inoculated agar plates were allowed to dry and were appropriately labelled. Using a plastic cork borer of $6 \mathrm{~mm}$ in diameter uniformed wells was bored in the inoculated nutrient agar. With a micropipette, $200 \mu 1$ of $10 \mathrm{mg} / \mathrm{ml}$ of each test compound solution was delivered into each well. Ciprofloxacin as the positive standard was also tested and the plates were left on the bench for 30minutes to allow the compound to diffuse into the agar. Thereafter, the plates were incubated at $37^{\circ} \mathrm{C}$ for $24 \mathrm{~h}$. After incubation, the plates were observed for inhibition zones around the wells. The diameters of the zones were measured with metre rule to the nearest whole millimetre and the results recorded in Table1. Minimum inhibitory concentration (MICs) was determined by broth dilution technique [22]. Different concentrations $(200,175,150,120,100,75,50,25,12.5,10.00) \mu \mathrm{g} / \mathrm{ml}$ of the test solution were evaluated. Specifically, $0.1 \mathrm{ml}$ of standardised inoculums $\left(1-2 \times 10^{7} \mathrm{CFU} / \mathrm{ml}\right)$ was added to test tubes and incubated for $24 \mathrm{~h}$ at $37^{\circ} \mathrm{C}$ and two controls (lank and standard) were maintained for each test sample. The lowest concentration (highest dilution) required to arrest the growth of bacteria was regarded as minimum inhibitory concentration (MIC) and the MICs of the test solution are recorded in Table2.

\section{Results and discussion}

Benzenesulponylchloride (6) have been successfully used as highly efficient and cost effective precursors for the synthesis of 2-phenylsulphonamide derivatives (7a-7e). Benzensulphonychloride (6) underwent condensation reaction with primary amine functionalities of five amino acids (1-5) in alkaline medium at the temperature below $0^{0} \mathrm{C}$ to produce 2-phenylsulphonamide derivatives of amino acids (7a-7e). (scheme1) 


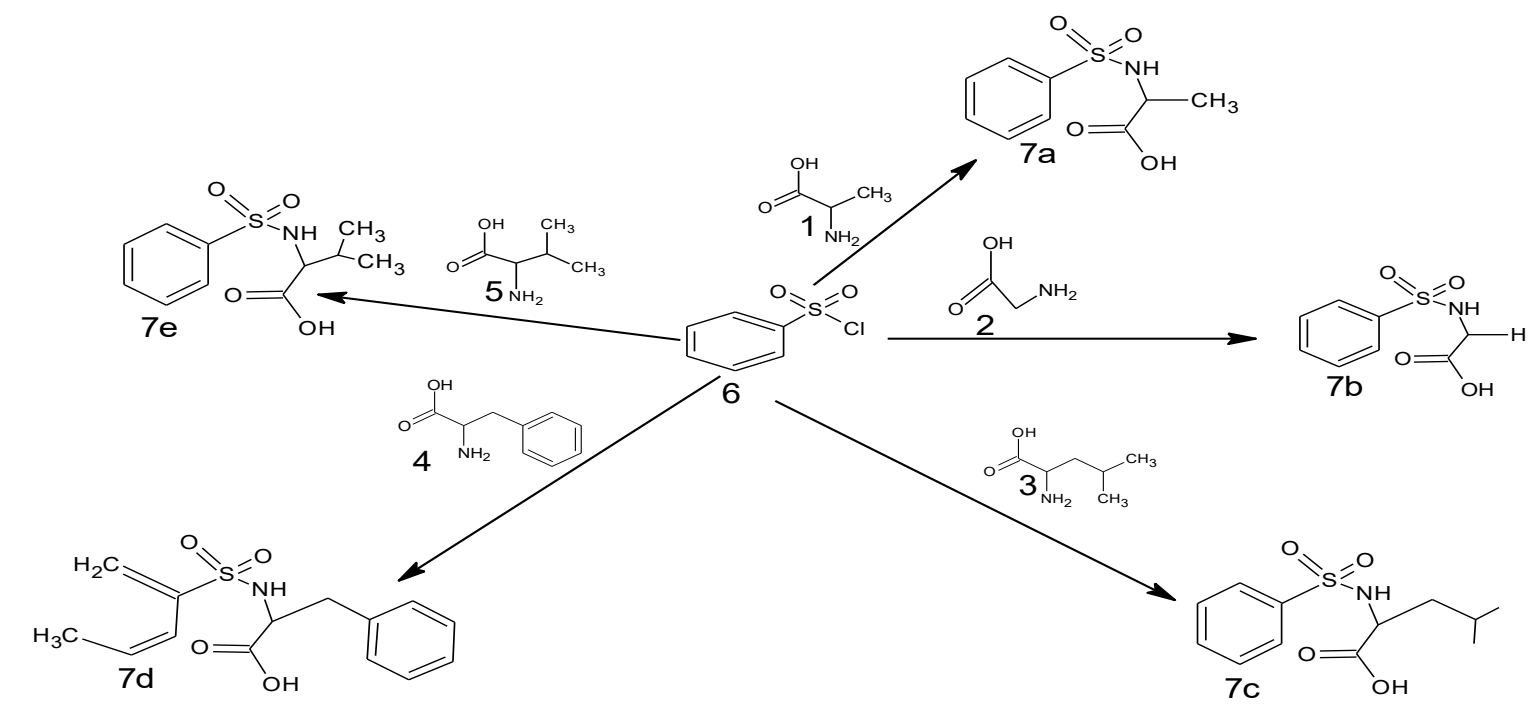

Scheme 1: Synthetic pathway of 2-phenylsulphonamide derivatives of amino acids (7a-7e).

The reaction started with conversion of the carboxylic end $(-\mathrm{COOH})$ of the amino acid to the sodium salt of the acid through electrophilic substitution of the $\mathrm{H}^{+}$with $\mathrm{Na}^{+}$released from the base $\left(\mathrm{Na}_{2} \mathrm{CO}_{3}\right)$. The formation of the sodium salt helped to protect the $(-\mathrm{COOH})$ of the amino acids and enhanced the solubility of the amino acids in aqueous medium.

The coupling of the amino acids with benzenesulphonyl chloride occurred by nucleophilic attack of the electrophilic sulphur by the amino group of the amino acids to form ammonium ion where chloride ion was the leaving group. The abstraction of the ammonium proton by the chloride ion led to the amide which underwent acidification with $20 \mathrm{Molar} \mathrm{HCl}$ to afford the expected 2-phenylsulphonamide derivatives (7a-7e).

The synthesised compounds were all white crystalline solids, having melting points $\left({ }^{0} \mathrm{C}\right)$ of $118-119,103-103,100-101,108-109$ and $141-142$ respectively. The FT-IR indicated the presence of $\mathrm{S}=\mathrm{O}$ at $(1162.11,1140.92,1162.65,1162.15,1167.94),-\mathrm{NH}-$ at $(3424.73,3417.01$, $3585.79,3423.76,3413.15),-\mathrm{C}=\mathrm{O}$ at $(1700.31,1719.60,1710.92,1686.81,1707.06)$ and -OH- signals at $(3315,3321.52,3248.23,3352.99,3310.92)$ for compounds $7 \mathbf{a}-7 \mathbf{e}$ respectively.

The proton spectra $\left({ }^{1} \mathrm{H}\right)$ showed chemical shift at $\delta 4.33-4.36$ for $-\mathrm{NH}-$ and $\delta 7.12-8.30$ for aromatic protons. Phenyl proton (7d) was observed at the stretched chemical shifts at $\delta 2.70-3.90$ with the same J. Value of $34.63 \mathrm{~Hz} .{ }^{13} \mathrm{C}$ NMR spectra showed chemical shifts at $170.70-173.69$ for carboxyl carbon. NMR data and elemental analytical data of the compounds have given further evidence for the confirmation of the synthesised compounds.

The antibacterial activities of the compounds were tested against Staphylococcus aurous, Pseudomonas aeruginosa, Streptococcus, klebsiella pneumonia, Escherichia coli and Proteus mirabilis. The compounds showed potent to moderate zone of inhibition by killing the bacteria strains at the concentration of $200 \mu \mathrm{l}$ of $10 \mathrm{mg} / \mathrm{ml}$ (Table 1). Result of the minimum inhibitory of the tested samples showed that $7 \mathrm{c}$ and $7 \mathrm{~d}$ exhibited more potent activity than the standard drugs while $7 \mathrm{e}$ was the same in Pseudomonas aeruginosa (Table2).

Table 1: Results of Anti-bacterial Activities of 2-phenylsulphonamides with $200 \mu 1 \mathrm{of} 10 \mathrm{mg} / \mathrm{ml}$ of compounds. Zone of Inhibition= [mm].

\begin{tabular}{ccccccc}
\hline COMPD & STAPH & STREP & E-COLI & PSEUDO & KLEB & PROTEUS \\
\hline $7 \mathrm{a}$ & 16 & 16 & 16 & 20 & 14 & 16 \\
$7 \mathrm{~b}$ & 16 & 17 & 20 & 21 & 14 & 16 \\
$7 \mathrm{c}$ & 16 & 16 & 20 & 22 & 16 & 16 \\
$7 \mathrm{~d}$ & 16 & 17 & 19 & 20 & 14 & 17 \\
$7 \mathrm{e}$ & 16 & 19 & 17 & 19 & 16 & 16 \\
CPX & 28 & 26 & 28 & 22 & 30 & 24 \\
\hline
\end{tabular}

$\mathrm{CPX}=$ Ciprofloxacin antibiotic drug (Positive Standard). 
Table 2: Minimum Inhibitory Concentration (MIC) in $\mu \mathrm{g} / \mathrm{ml}$ of 2-phenylsulphonamides Derivatives (7a-7e).

\begin{tabular}{ccccccc}
\hline COMPD & STAPH & STREP & E-COLI & PSEUDO & KLEB & PROTEUS \\
\hline $7 \mathrm{a}$ & 120 & 120 & 100 & 50 & 200 & 120 \\
$7 \mathrm{~b}$ & 100 & 75 & $>50$ & 25 & 200 & 100 \\
$7 \mathrm{c}$ & 100 & 100 & 25 & 12.5 & 120 & 100 \\
$7 \mathrm{~d}$ & $>75$ & $>75$ & 50 & 12.5 & 175 & $>75$ \\
$7 \mathrm{e}$ & 100 & 50 & 75 & $>12.5$ & 150 & 100 \\
$\mathrm{CPX}$ & 10 & 12.5 & $>12.5$ & $>12.5$ & 5.0 & 25 \\
\hline \multicolumn{7}{c}{ CPX=Ciprofloxacin antibiotic drug (Positive Standard). }
\end{tabular}

\section{Conclusions}

2-phenylsulphonamide derivatives of amino acids (7a-7e) have been successfully synthesised with benzenesulphonylchloride (6) and amino acids (1-5). The synthesised compounds are broad spectrum antibiotics since they showed zone of inhibition on the growth of both gram positive bacteria such as Staph and Streptococcus and gram negative bacteria like E-coli, Klebsiella, Proteus, and pseudomonas. The MIC results (Table2) showed that compounds $7 \mathrm{c}$ and $7 \mathrm{~d}$ can be classed as more potent anti bacteria agents against Pseudomonas aeruginosa than the standard drug ciprofloxacin.

\section{References}

[1] G.I. Mandell et al., (Goodman ed). The pharmacolical bases at therapeutics, $9^{\text {th }}$ ed. McGrawHill New York. (1996).

[2] T. Narasaiah et al., Synthesis of New Sulphonamide Derivatives of Tryptamine and Their Antibacterial Activity. Der. Pharm. Chem. 4(4): (2012). 1582-1590.

[3] T. Owa, T. Nagasu. Novel sulfonamide derivatives for the treatment of cancer. Exp opin Ther pat. 10: (2000) 1725-1740.

[4] R.C. Ogden, C.W. Flexner. Protease inhibitors in AIDS therapy. New York, U.S.A, Marcel Dekker. (2001).

[5] C.W. Thombe, Isosterism and molecular modification in drug design. Chem. Soc Rev. 8: (1979) 563-580.

[6] I. Nishimori et al., Carbonic anhydrase inhibitors. Inhibition of the transmembran isozyme XIV with sulfonamides. Bio-Org. Med. chem. Let., 15: (2005) 3828-3833.

[7] J.J. Li et al., Indisulam. J. Med Chem. 38: (1995) 4570.

[8] A. Boyd. Sulfonylurea receptors, ion channels and fruit flies. Diabetes 37: (1988) 847-850.

[9] T.S. Claudiu, C. Angela, S. Andrea. Med. Res. Rev. 23: (2003) 535-558.

[10] A. Shimizu, R. Ikonna, T. Shimizu. Effect and side effect of Zonisamide during long term medication. Curi ther. Res. 47: (1990) 696-706.

[11] M.J. Yelland et al., Celecoxib Compared with sustained-release Paracetamol for Osteoarthritis: a series of n-of-1 trials. Rheumatology (oxford) 46: (2007) 135-140.

[12] R.D. Tung, M.A. Murcko, G.R. Bhisetti. Sulphonamide inhibitors of HIV-as party protease. (1994) EPO 65918, US 5585397.

[13] F.C. Hans, E. Jawetz. Basic and chemical pharmacology. katzung, B.G. (ed) appletonlange 1998, 761-763.

[14] P. Verhaeghe et al., Synthesis and Antiplasmodial Activity of new 4-aryl-2trichloromethylquinazolines. Bioorg. Med. chem. Let. 18: (2008) 396-401.

[15] U. David, C.U. Okoro. Synthesis, Characterisation and Antifungal Activities of [4Methylphenylsulphonamido]-N-Acetamide Derivatives. Med chem. 2014, 4(2): 330-333. 
[16] S. Siliveru, T. Parthsurathy. Synthesis of Sulphonamide Schiff bases and their Biological Evaluation towards Colletotrichum gleosporioides. Int. J. Pharmacy 3(11): (2012) 213-215.

[17] T. Narasaiah et al., Synthesis of New Sulphonamide Derivatives and Tryptamine and Yheir Antimicrobial Activity. Der Pharma Chemica 4(4): (2012) 1582-1590.

[18] M.B. John (Jr.), H.B. John. Wilson Gisvold textbook of Organic Chemistry. 12 (ed.), Lippincolt Williams and Wilkins 2011, 240.

[19] C.B.C. Ikpa, U.C. Okoro. Synthesis of New Paratoluene Sulphonamide Derivatives of Amino Acids And Their Anti Bacterial Activities. IOSR Journal Of Applied Chem. (IOSR-JAC). 9(6) Ver. II. (2016) 31-34.

[20] B.S. Furniss et al., Vogel Practical Organic Chem. Longman and ELBS (2005) 1140-1141.

[21] B.A. Adeniyi, H.A. Odelola. Anti-microbial potentials of Diospyros mespiliformis. African journal of medicinal science, 25: (I996) 221-224.

[22] G.H. Bonjar Shahidi. Asian Journal of Science. 3(1), (2004) 82-84. 